\title{
Zespół utraty białek u pacjentów z pojedynczą komorą serca po operacji Fontana
}

\section{Protein-losing enteropathy in patients with single ventricle after Fontan operation}

\author{
Edward Malec, Katarzyna Januszewska
}

Klinika Kardiochirurgii Dziecięcej Westfalskiego Uniwersytetu Wilhelma w Münster

\section{Streszczenie}

Po ponad 40 latach leczenia serca jednokomorowego sposobem Fontana istnieje obecnie duża grupa pacjentów narażonych na dotychczas mało poznane powikłania, do których należy zespół utraty białek z przewodu pokarmowego. W artykule omówiono współczesne teorie dotyczące etiologii i patomechanizmów rozwoju, przedstawiono obraz kliniczny, a także zaprezentowano dostępne metody diagnostyczne i lecznicze zespołu.

Słowa kluczowe: serce jednokomorowe, operacja Fontana, zespół utraty białek

Folia Cardiologica 2016; 11, 3: 238-244

\section{Wstęp}

W związku z rozwojem kardiochirurgii i kardiologii dziecięcej zwiększa się liczba pacjentów z pojedynczą komorą serca po operacji Fontana. Po ponad 40 latach leczenia sposobem Fontana istnieje obecnie duża grupa pacjentów, młodzieży i dorosłych, narażonych na nowe i mało dotychczas poznane powikłania. Stanowi to niezwykle trudne wyzwanie nie tylko dla kardiologów, ale również dla lekarzy innych specjalności.

Operacja Fontana jest ostatnim etapem leczenia chirurgicznego chorych z sercem jednokomorowym [1]. Jedyna istniejąca komora serca u tych pacjentów pompuje krew do krążenia systemowego. Przepływ krwi przez płuca odbywa się w sposób bierny, pod ciśnieniem żylnym. Podstawowym celem operacji Fontana jest rozdzielenie dwóch układów krążenia i poprawa utlenowania organizmu. W związku z brakiem komory pompującej krew do krążenia płucnego, znacznie wzrasta ciśnienie w systemowym układzie żylnym. Operacja Fontana nie przywraca prawidłowych warunków hemodynamicznych w układzie krążenia, ale umożliwia ludziom z pojedynczą komorą przeżycie i w miarę normalne funkcjonowanie. Pacjenci po operacji Fontana narażeni są jednak na szereg powikłań, takich jak: niewydolność krążenia, ograniczenie wydolności wysiłkowej, zaburzenia rytmu serca, zatory i zakrzepy, opóźnienie rozwoju fizycznego, niewydolność wątroby, zespół utraty białek (PLE, protein loosing enteropathy) i plastyczne zapalenie oskrzeli (BP, bronchitis plastica) [2-4].

Zespół utraty białek z przewodu pokarmowego jest jednym z najcięższych i najbardziej intrygujących powikłań wrodzonych wad serca. Pojawia się zwykle nagle i nieoczekiwanie (od kilku tygodni do kilku lat po operacji Fontana, średnio po 3,5 roku) i charakteryzuje się masywną utratą białek do przewodu pokarmowego, zazwyczaj przy prawidłowym funkcjonowaniu innych narządów [5].

\section{Patomechanizm zespołu utraty białka}

Utrata białek jest spowodowana z jednej strony uszkodzeniem błony śluzowej przewodu pokarmowego i wzrostem jej przepuszczalności dla białek osocza, z drugiej strony upośledzonym wchłanianiem z przewodu pokarmowego białek dostarczanych z pokarmem. Białka przedostające 
się z krwi do przewodu pokarmowego są szybko degradowane do aminokwasów. Większość aminokwasów jest z powrotem wchłaniana do krążenia wrotnego. Zespół utraty białek objawia się klinicznie wówczas, gdy utrata białek przewyższa możliwości ich resyntezy z aminokwasów w wątrobie. W związku z podwyższonym ciśnieniem w naczyniach limfatycznych przewodu pokarmowego i ich poszerzeniem zdolności absorpcyjne błony śluzowej są znacznie ograniczone. Stężenie w surowicy białek, których cykl rozpadu i resyntezy jest wolniejszy (albuminy i niektóre immunoglobuliny), obniża się znacznie szybciej niż innych białek, o szybszym cyklu, takich jak insulina. Zespół utraty białek może być również rezultatem uszkodzenia błony śluzowej przewodu pokarmowego w wyniku procesów chorobowych w innych zaburzeniach układu krążenia (np. kardiomiopatie, zaciskające zapalenie osierdzia, stan po operacji Mustarda lub Senninga), których wspólną cechą jest upośledzenie powrotu krwi do serca z żył systemowych i wzrost systemowego ciśnienia żylnego [6]. Ponadto PLE może się rozwinąć również w schorzeniach pozasercowych, takich jak: choroby przewodu pokarmowego (celiakia), limfangiektazje jelitowe czy choroby o podłożu autoimmunologicznym [7]. Zaburzenia wchłaniania z przewodu pokarmowego oprócz białek dotyczą również długołańcuchowych trójglicerydów i tłuszczów.

U pacjentów z PLE często dochodzi do poważnych zaburzeń immunologicznych. Zmiany w układzie immunologicznym dotyczą zarówno odporności komórkowej, jak i humoralnej. Obniża się liczba limfocytów T, głównie populacji CD4+ i CD8+, przy czym dominuje utrata limfocytów CD4+, powodując obniżenie stosunku limfocytów CD4+ do limfocytów CD8+ [7]. Podobne zjawisko występuje u pacjentów z ludzkim wirusem nabytego upośledzenia odporności (HIV, human immunodeficiency virus) [8]. W zakresie odporności humoralnej obserwuje się znaczny spadek stężenia immunoglobulin. Spadek stężenia gammaglobulin w surowicy jest związany nie tylko z ich utratą z przewodu pokarmowego, ale także ze zmniejszoną ich produkcją. Niektóre zburzenia w układzie immunologicznym, takie jak obecność przeciwciał przeciwjądrowych, obserwuje się u pacjentów po operacji Fontana jeszcze przed pojawieniem się objawów PLE [9].

Zaburzenia w układzie krzepnięcia ze współistniejącym spadkiem stężeń białek C i S pojawiają się we wczesnych stadiach PLE, jeszcze przed wystąpieniem klinicznie uchwytnych objawów i przy prawidłowym stężeniu albumin w surowicy krwi [4].

\section{Etiologia}

W patogenezie PLE bierze udział wiele czynników okołooperacyjnych, hemodynamicznych, zapalnych, genetycznych i immunologicznych. Najbardziej prawdopodobną przyczyną rozwoju PLE z przewodu pokarmowego są predyspozycje genetyczne, a czynniki hemodynamiczne mogą być czynnikami wyzwalającymi.

\section{Czynniki hemodynamiczne}

Przewlekle podwyższone ciśnienie żylne i związany z tym wzrost ciśnienia w przewodzie piersiowym i naczyniach limfatycznych uważa się za bezpośrednie przyczyny PLE. Przewlekły zastój żylny powoduje przeciek chłonki z naczyń limfatycznych do niskociśnieniowych przestrzeni, takich jak jama opłucnowa i otrzewnowa. U wielu jednak pacjentów po operacji Fontana, nawet ze znacznie podwyższonym ciśnieniem żylnym, nie obserwuje się objawów PLE. Ponadto obniżenie centralnego ciśnienia żylnego w wyniku reoperacji lub interwencji kardiologicznej (usunięcie zwężeń, wykonanie fenestracji) często nie prowadzi do ustąpienia objawów PLE. Takie obserwacje zmuszają więc do poszukiwania innych czynników odpowiedzialnych za rozwój schorzenia.

Często podkreśla się rolę zmniejszonego rzutu serca i podwyższonego oporu naczyń krezkowych. W wyniku długotrwale utrzymującego się niskiego rzutu serca dochodzi do uruchomienia mechanizmów kompensacyjnych i redystrybucji przepływu krwi do ważnych dla życia narządów, kosztem innych, na przykład przewodu pokarmowego. U pacjentów po operacji Fontana, szczególnie u tych, u których stwierdzono PLE, wykazano podwyższony opór naczyń krezkowych [10-12].

\section{Czynniki związane z operacją i okresem okołooperacyjnym}

Do ważnych czynników ryzyka rozwoju PLE należy prawdopodobnie czas krążenia pozaustrojowego w czasie operacji Fontana i związane z tym zaburzenia (uszkodzenie miocytów, uogólniona reakcja zapalna z uwolnieniem cytokin) $[13,14]$. Długi czas krążenia pozaustrojowego podczas operacji w skojarzeniu z podwyższonym ciśnieniem żylnym może prowadzić do trwałego uszkodzenia naczyń krezkowych oraz limfatycznych i predysponować do rozwoju PLE [15].

Zaobserwowano również, że u pacjentów, u których w przebiegu pooperacyjnym doszło do niewydolności nerek, w okresie odległym częściej występuje PLE [16]. Nie wiadomo jedynie, czy PLE jest konsekwencją niewydolności nerek, czy też niewydolność nerek jest związana z zaburzeniami hemodynamicznymi, objawiającymi się po raz pierwszy we wczesnym okresie pooperacyjnym.

Prawdopodobnie uszkodzenia powstające w czasie operacji związanie z perfuzją pozaustrojową (uwolnienie cytokin, uszkodzenie reperfuzyjne, uszkodzenie miocytów) są potencjalnymi czynnikami odpowiadającymi za rozwój PLE w okresie odległym $[13,14]$.

\section{Morfologia pojedynczej komory}

Zespół utraty białka obserwuje się częściej u pacjentów z pojedynczą morfologicznie prawą komorą serca [15]. 
Prawa komora serca różni się pod względem anatomicznym i czynnościowym od lewej. Silvilairat i wsp. wykazali, że istotnym czynnikiem ryzyka rozwoju PLE jest obniżona funkcja skurczowa komory oraz morfologia prawej komory serca jednokomorowego [17].

\section{Czynniki infekcyjne}

Czynnikiem wywołującym PLE mogą być zakażenia bakteryjne lub wirusowe przewodu pokarmowego [18]. W śluzowce jelit, w ostrym okresie PLE, wykazano wzrost stężenia interferonu gamma (IFN-y) i czynnika martwicy guzów (TNF- $\alpha$, tumor necrosis factor alpha). Prawdopodobnie wzrost stężenia tych prozapalnych cytokin jest reakcją na zakażenie wirusowe $[19,20]$. Obydwie te cytokiny uszkadzają barierę nabłonkową jelit, prowadząc do zwiększonej przepuszczalności. Taką hipotezę, jako jednego z czynników etiologicznych PLE, może potwierdzać zazwyczaj pozytywna odpowiedź na leczenie steroidami [19].

\section{Czynniki genetyczne}

Genetyczne predyspozycje mogą istnieć u pacjentów z mutacją genu odpowiadającego za produkcję siarczanu heparanu. W błonie podstawnej enterocytów pacjentów z PLE wykazano zmniejszoną zawartość siarczanu heparanu, co może prowadzić do wzrostu przepuszczalności błony śluzowej dla albumin [10, 21, 22]. Pozytywny efekt podawania heparyny u pacjentów z PLE prawdopodobnie jest wynikiem substytucji siarczanu heparanu w błonie podstawnej enterocytów. Heparyna może działać również przeciwzapalnie. W badaniach doświadczalnych wykazano, że deficyt siarczanu heparanu w błonie enterocytów i wzrost stężenia cytokin INF-y i TNF- $\alpha$, jako czynniki występujące osobno, mają tylko niewielki wpływ na przepuszczalność nabłonka jelitowego. Obniżona zawartość siarczanu heparanu współistniejąca jednak z wysokim stężeniem prozapalnych cytokin prowadzi do znacznego uszkodzenia nabłonka jelitowego [23].

\section{Czynniki immunologiczne}

O znaczeniu zaburzeń immunologicznych w patogenezie PLE może świadczyć obecność immunologicznych kompleksów, aktywacja układu dopełniacza oraz selektywna utrata limfocytów CD4+ [7, 24]. Niektóre zaburzenia immunologiczne spotykane u pacjentów z PLE obserwuje się $u$ chorych ze schorzeniami autoimmunologicznymi, na przykład obecność przeciwciał przeciwjądrowych [25]. Na podstawie analizy immunologicznego fenotypu oraz jego zmian można obecnie wykazać, którzy pacjenci po operacji Fontana są narażeni na ryzyko rozwoju PLE [9, 25], oraz wdrożyć wczesną zindywidualizowaną terapię.

\section{Inne czynniki}

Według jednej z hipotez pacjenci, u których w okresie pooperacyjnym występują przesięki do opłucnych o cha- rakterze chłonki lub w okresie późniejszym rozwija się PLE, mają niezdiagnozowane wrodzone zaburzenia układu limfatycznego. Taka hipoteza jest trudna do potwierdzenia w związku z trudnościami w precyzyjnym obrazowaniu układu limfatycznego, związanymi z brakiem adekwatnej metody diagnostycznej.

Postulowano również, że podwyższone stężenie przedsionkowego peptydu natriuretycznego (ANP, atrial natriuretic peptide) w surowicy krwi po operacji Fontana bierze udział w rozwoju PLE poprzez hamowanie przepływu chłonki. Jest to związane z redukcją przez ANP kurczliwości mięśni gładkich naczyń limfatycznych krezki [26].

\section{Obraz kliniczny}

Zespół utraty białek dotyczy 4-11\% pacjentów z pojedynczą komorą po operacji Fontana $[10,16]$. Masywna utrata białek do światła przewodu pokarmowego prowadzi do obniżenia stężenia albumin oraz białka całkowitego w osoczu i spadku śródnaczyniowego ciśnienia onkotycznego. Klinicznie schorzenie manifestuje się obrzękami, wodobrzuszem, przesiękami do jam surowiczych i zaburzeniami ze strony przewodu pokarmowego. Uporczywe biegunki są jednym z najczęstszych objawów PLE. Biegunka pojawia się często, ale nie zawsze i w wielu przypadkach obserwuje się stopniowy rozwój zespołu i powolną utratę białek ze stolcem.

U niektórych pacjentów PLE ma charakter przejściowy, związany z infekcją lub możliwymi do usunięcia zaburzeniami hemodynamicznymi. U tych chorych objawy PLE zwykle ustępują po wyleczeniu infekcji lub usunięciu przyczyn zaburzeń hemodynamicznych.

U pacjentów z PLE dochodzi do zahamowania rozwoju fizycznego i utraty masy ciała [27]. Utrata białek i limfocytów oraz uogólniona reakcja zapalna towarzysząca temu zespołowi prowadzą do niedożywienia, wyniszczenia, zaburzeń wodnoelektrolitowch i upośledzenia odporności. Pomimo stwierdzanych zaburzeń w zakresie odporności humoralnej oraz komórkowej u pacjentów z PLE rzadko obserwuje się ciężkie zakażenia wirusowe lub bakteryjne [7, 24] i profilaktyka farmakologiczna zakażeń u tych pacjentów nie jest wskazana.

Powikłania zatorowe i zaburzenia krzepnięcia krwi obserwowane po operacji Fontana prawdopodobnie są wywołane nie tylko przez zwolnienie przepływu krwi w układzie żylnym, ale mogą być spowodowane również obniżonym stężeniem białka C i S [4]. Około 50\% pacjentów z PLE przeżywa 5 lat od chwili wystąpienia pierwszych objawów, a 10 lat tylko $10-20 \%[5,16]$.

\section{Diagnostyka}

Zespół utraty białek należy różnicować z innymi schorzeniami przebiegającymi z hipoproteinemią, takimi jak: pierwotne uszkodzenie błony śluzowej przewodu pokarmowego, 
wrodzone deficyty enzymatyczne, zespół nerczycowy oraz zaburzenia odporności. Zaburzenia w układzie krzepnięcia ze współistniejącym spadkiem stężeń białek C i S obserwuje się we wczesnych stadiach PLE, jeszcze przed wystąpieniem klinicznie uchwytnych objawów i przy prawidłowym stężeniu albumin w surowicy krwi [4].

Najważniejsze laboratoryjne kryteria diagnostyczne to:

- obniżenie stężenia białka całkowitego, albumin i gammaglobulin w surowicy krwi;

- podwyższone stężenie $\alpha 1$-antytrypsyny w stolcu i w surowicy krwi;

- wzrost stężenia $\alpha_{1^{-}}, \alpha_{2}$ - i $\beta$-globulin w surowicy krwi;

- prawidłowe stężenie białka w moczu;

- limfopenia;

- możliwe podwyższenie parametrów stanu zapalnego, takich jak IL-6, IL-8, TNF- $\alpha$.

\section{Leczenie}

Zespół utraty białek do przewodu pokarmowego jest bardzo trudny do leczenia ze względu na nie w pełni wyjaśnioną etiologię. Kluczem do skutecznego leczenia może być wczesne wykrycie. Okresowe badania stężenia białek w surowicy oraz $\alpha 1$-antytrypsyny mogą być pomocne we wczesnym ustaleniu rozpoznania, jeszcze przed wystąpieniem pełnoobjawowego zespołu. Fujii i wsp. w swoich badaniach wykazali, że PLE rozpoczyna się wcześniej, niż pojawiają się takie objawy jak biegunka czy hipoproteinemia [28]. Wczesnym markerem PLE jest wzrost $\alpha_{1}$-antytrypsyny w stolcu [29], natomiast monitorowanie stężenia $\alpha_{1}$-antytrypsyny $w$ trakcie leczenia może dawać obraz jego skuteczności [30].

Okresowe badanie układu immunologicznego pacjentów po operacji Fontana jest użyteczne w wykryciu osób narażonych na ryzyko rozwoju PLE. Istotne znaczenie w tych badaniach ma określenie liczby i funkcji limfocytów T [9].

Strategia leczenia powikłań po operacji Fontana powinna być ukierunkowana na poprawę rzutu serca i obniżenie centralnego ciśnienia żylnego. Po wystąpieniu pierwszych objawów należy wykluczyć wszelkie „usuwalne” nieprawidłowości strukturalne i zaburzenia hemodynamiczne, jak na przykład zwężenie drogi wypływu z pojedynczej komory, utrudnienie dopływu krwi żylnej do układu tętnicy płucnej, niedomykalność zastawek serca czy przetoki naczyniowe. Przeprowadzenie cewnikowania serca jest bezwzględnie wskazane u wszystkich pacjentów z PLE. Stwierdzenie zaburzeń anatomicznych, takich jak zwężenie tętnic płucnych, niedomykalność zastawek przedsionkowo-komorowych czy zwężenie podzastawkowe aorty, jest wskazaniem do reoperacji lub interwencji kardiologicznej.

U pacjentów z połączeniem prawego przedsionka z tętnicą płucną (klasyczna operacja Fontana) istotną poprawę często przynosi zamiana na zespolenie pozasercowe lub wewnątrzprzedsionkowy tunel w celu ułatwienia przepływu krwi i redukcji objętości przedsionka. Jeżeli występują zaburzenia rytmu serca, wówczas w czasie takiej operacji wykonuje się ablację i/lub wszczepia rozrusznik serca. Bardzo istotne znaczenie ma przywrócenie prawidłowej synchronizacji przedsionkowo-komorowej [31-34].

U wielu pacjentów poprawa może nastąpić po wykonaniu fenestracji (wytworzeniu komunikacji pomiędzy „układem Fontana” a lewym przedsionkiem). Fenestracja umożliwia „prawo-lewy” przeciek, czyli przypływ krwi żylnej do lewego przedsionka, powodując tylko niewielkie zmniejszenie utlenowania organizmu. Tak wytworzona komunikacja prowadzi do poprawy wypełnienia komory i zwiększenia rzutu serca. Po wykonaniu fenestracji zwykle obniża się centralne ciśnienie żylne. Fenestracja może być wykonana w czasie cewnikowania serca lub reoperacji [35-37].

Wszyscy pacjenci z PLE wymagają leczenia farmakologicznego. Należy wdrożyć leczenie skierowane na poprawę pojemności minutowej serca, obniżenie centralnego ciśnienia żylnego oraz leki przeciwobrzękowe i przeciwzakrzepowe. Zmniejszenie obciążenia następczego uzyskuje poprzez wprowadzenie inhibitorów konwertazy angiotensyny (ACE, angiotensin-converting enzyme) lub antagonistów receptorów angiotensynowych. U wszystkich pacjentów należy wprowadzić spironolakton, który nie tylko działa moczopędnie, ale ma również korzystne działanie bezpośrednio na mięsień sercowy (ułatwiając tzw. remodeling mięśnia sercowego) [38].

U pacjentów z podwyższonym ciśnieniem w krążeniu płucnym należy wprowadzić sildenafil. Lek ten zmniejsza opór naczyń krążenia płucnego, obniża obciążenie następcze oraz poprawia przepływ krwi przez naczynia krezkowe. W wielu doniesieniach wykazano korzystne działanie sildenafilu poprzez obniżenie naczyniowego oporu płucnego i poprawę przepływu przez krążenie płucne. Istnieją doniesienia o ustąpieniu objawów PLE i plastycznego zapalenia oskrzeli oraz poprawie wydolności wysiłkowej pacjentów po wprowadzeniu sildenafilu $[39,40]$.

Jeżeli domniemaną przyczyną PLE są czynniki zapalne, zasadne może być wprowadzenie kortykoterapii [41, 42]. Ostatnio pojawiły się doniesienia o korzystnym działaniu budesonidu, steroidu podawanego doustnie, który działa głównie na poziomie śluzówki przewodu pokarmowego, a ponieważ jego wchłanianie do krwi jest niewielkie, ma on mniejsze niż inne steroidy działanie ogólnoustrojowe $[43,44]$.

Skuteczność działania heparyny u niektórych pacjentów przedstawili Donnelly i wsp. [45]. Korzystny efekt może być spowodowany przeciwzapalnym działaniem heparyny poprzez zmniejszenie rozpadu mastocytów w jelitach i wiązanie prozapalnych cytokin [23]. Heparyna stabilizuje również błonę podstawną enterocytów stanowiącą barierę dla 
ucieczki cząsteczek białek osocza [22]. Poprzez działanie przeciwzakrzepowe zmniejsza ryzyko mikrozatorów w krążeniu płucnym i krezkowym [46]. U wszystkich pacjentów po operacji Fontana stwierdza się zaburzenia w układzie krzepnięcia krwi. W związku z tym nawet pacjenci bez zespołu utraty białek powinni rutynowo otrzymywać leki przeciwzakrzepowe, z tego względu też przeciwwskazane jest stosowanie doustnych leków antykoncepcyjnych.

Bardzo istotne znaczenie w leczeniu PLE ma wprowadzenie odpowiedniej diety. Dieta powinna być wysokobiałkowa i zawierać co najmniej 2 g białka na kilogram masy ciała na dobę oraz bogata w średniołańcuchowe trójglicerydy. Takie trójglicerydy wchłaniane są bezpośrednio, przez naczynia krwionośne układu wrotnego, z pominięciem naczyń limfatycznych. Ze względu na częste wyniszczenie tych pacjentów, bardzo istotne znaczenie ma dostarczenie odpowiedniej liczby kalorii [10, 27].

Przeszczepienie serca jest w zasadzie jedyną skuteczną chirurgiczną opcją terapeutyczną dla wielu pacjentów, u których zawiodły inne metody leczenia [47]. Transplantacja serca po operacji Fontana jest zabiegiem trudnym technicznie ze względu na złożone warunki anatomiczne, stan pacjenta oraz przebyte operacje. Przeszczepienie serca zwykle nie natychmiast, ale w przeciągu kilku miesięcy prowadzi u większości pacjentów do ustąpienia objawów PLE. Warunkiem powodzenia takiej terapii jest właściwy dobór pacjentów i wczesne skierowanie pacjenta do transplantacji $[48,49]$.

Wielu pacjentów wymaga okresowego uzupełniania albumin i/lub gammaglobulin w celu złagodzenia objawów hipoproteinemii. Wzrost ciśnienia onkotycznego po infuzji białka prowadzi do zmniejszenia obrzęków [10]. Częstość infuzji albumin i immunoglobulin powinna być podyktowana stanem pacjenta.

W związku z nie do końca poznaną etiologią i mało skuteczną terapią zachodzi konieczność zintensyfikowania badań nad zespołem utraty białek do przewodu pokarmowego. Obecnie jedynym zalecanym sposobem prewencji PLE może być zaostrzenie kryteriów kwalifikacji pacjentów z pojedynczą komorą do operacji Fontana i wyeliminowanie tych, którzy obarczeni są istotnymi czynnikami ryzyka. Wczesne przeprowadzenie operacji Fontana może również przyczynić się do poprawy wyników odległych.

Na wiele pytań dotyczących zespołu utraty białek nie poznano odpowiedzi. Do najbardziej nurtujących z nich należą następujące kwestie:

- dlaczego PLE rozwija się tylko u niektórych pacjentów po operacji Fontana, pomimo podobnych warunków hemodynamicznych i morfologii wady serca?

- dlaczego u niektórych pacjentów PLE rozwija się kilka miesięcy po operacji, a u innych dopiero po kilku latach?

- dlaczego u wielu pacjentów, pomimo poprawy warunków hemodynamicznych, objawy nie ustępują?

- jeżeli za czynnik etiologiczny uważa się podwyższone ciśnienie żylne, dlaczego po wykonaniu fenestracji i obniżeniu ciśnienia żylnego tylko u niewielu pacjentów następuje poprawa?

- dlaczego korzystny efekt dość często przynosi zastosowanie steroidów i heparyny, które w zasadzie nie wpływają na wysokość ciśnienia żylnego, czynnika najczęściej uznawanego za odpowiedzialny za rozwój PLE?

\section{Abstract}

After more than 40 years of treatment of single-ventricle heart with the Fontan pathway there is a large group of patients exposed to poorly known complications, such as a protein-losing enteropathy. The article discuses contemporary theories regarding the etiology and pathomechanisms of this syndrome, presents the clinical picture and available diagnostic and therapeutic methods.

Key words: single-ventricle heart, Fontan operation, protein losing-enteropathy

Folia Cardiologica 2016; 11, 3: 238-244

\section{Piśmiennictwo}

1. Fontan F., Bauder E. Surgical repair of tricuspid atresia. Thorax 1971; 26: $240-248$.

2. Anderson P.A.W., Sleeper L.A., Mahony L. i wsp., for the Pediatric Heart Network Investigators. Contemporary outcomes after the Fontan procedure: a Pediatric Heart Network Multicenter Study. J. Am. Coll. Cardiol. 2008; 52: 85-98.
3. Paridon S.M., Mitchell P.D., Colan S.D. i wsp., for the Pediatric Heart Netword Investigators. A cross-sectional study of exercise performance during the first 2 decades of life after the Fontan operation. J. Am. Coll. Cardiol. 2008; 52: 99-107.

4. Cromme-Dijkuis A.H., Henkens C.M., Bijleveld C.M., Hillege H.L., Bom V.J., van der Meer J. Coagulation factor abnormalities as pos- 
sible thrombotic risk factors after Fontan operations. Lancet 1990; 336: 1087-1090.

5. Mertens L., Hagler D.J., Sauer U., Somerville J., Gewillig M. Protein-losing enteropathy after the Fontan operation: an international multicenter study. PLE study group. J. Thorac. Cardiovasc. Surg. 1998; 115: 1063-1073.

6. Moodie D.S., Feldt R.H., Wallace R.B. Transient protein-losing enteropathy secondary to elevated caval pressures and caval obstruction after the Mustard procedure. J. Thorac. Cardiovasc. Surg. 1976; 72 : 379-382.

7. Cheung Y.F., Tsang H.Y., Kwok J.S. Immunologic profile of patients with protein-losing enteropathy complicating congenital heart disease. Pediatr. Cardiol. 2002; 23: 587-593.

8. Zaccarelli-Filho C.A., Ono E., Machado D.M. i wsp. HIV-1-infected children on HAART: immunologic features of three different levels of viral suppression. Cytometry B Clin. Cytom. 2007; 72B: 14-21.

9. Lenz D., Hambsch J., Schneider P., Tárnok A. Protein-losing enteropathy after Fontan surgery is assessment of risk patients with immunological data possible? Cytometry B Clin. Cytom. 2003; 53B: 34-39.

10. Rychik J. Protein-losing enteropathy after Fontan operation. Congenit. Heart Dis. 2007; 2: 288-300.

11. Crupi G., Locatelli G., Tiraboschi R., Villani M., De Tommasi M,, Parenzan L. Protein-losing enteropathy after Fontan operation for tricuspid atresia (imperforate tricuspid valve). Thorac. Cardiovasc. Surg. 1989; 28: 359-363.

12. Rychik J., Gui-Yang S. Relation of mesenteric vascular resistance after Fontan operation and protein-losing enteropathy. Am. J. Cardiol. 2002; 90: 672-674.

13. Tarnok A., Hambsch J., Emmrich F. i wsp. Complement activation, cytokines, and adhesion molecules in children undergoing cardiac surgery with or without cardiopulmonary bypass. Pediatr. Cardiol. 1999; 20: 113-125.

14. Hill R.E., Hercz A., Corey M.L. i wsp. Fecal clearance of alpha 1-antitrypsin: a reliable measure of enteric protein loss in children. J. Pediatr. 1981; 99: 416-418.

15. Powell A.J., Gauvreau K., Jenkins K.J., Blume E.D., Mayer J.E., Lock J.E. Perioperative risk factors for development of protein-losing enteropathy following a Fontan procedure. Am. J. Cardiol. 2001; 88: 1206-1209.

16. Feldt R.H., Driscoll D.J., Offord K.P. i wsp. Protein-losing enteropathy after the Fontan operation. J. Thorac. Cardiovasc. Surg. 1996; 112: 672-680.

17. Silvilairat S., Cabalka A.K., Cetta F., Grogan M., Hagler D.J., O'Leary P.W. Protein-losing enteropathy after the Fontan operation: associations and predictors of clinical outcome. Congenit. Heart Dis. 2008; 3: $262-268$.

18. Lenz D., Hambsch J., Schneider P. i wsp. Protein-losing enteropathy in patients with Fontan circulation: is it triggered by infection? Crit. Care 2003; 7: 185-190.

19. Shimizu T., Nagata S., Fujii T. i wsp. Enhanced production of interferon gamma as a possible cause of protein-losing enteropathy after modified Fontan operation. J. Pediatr. Gastroenterol. Nutr. 2003; 37: 504-507.

20. Ostrow A.M., Freeze H., Rychik J. Protein-losing enteropathy after Fontan operation: investigations into possible pathophysiologic mechanisms. Ann. Thorac. Surg. 2006; 82: 695-700.

21. Vernier R.L., Klein D.J., Sisson S.P., Mahan J.D., Oegema T.R., Brown D.M. Heparan sulfate-rich anionic sites in the human glomeru- lar basement membrane. Decreased concentration in congenital nephrotic syndrome. N. Engl. J. Med. 1983; 309: 1001-1009.

22. Westphal V., Murch S., Kim S. i wsp. Reduced heparan sulfate accumulation in enterocytes contributes to protein-losing enteropathy in a congenital disorder of glycosylation. Am. J. Pathol. 2000; 157: 1917-1925.

23. Bode L., Murch S., Freeze H. Heparan sulfate plays a central in a dynamic in vitro model of protein-losing enteropathy. J. Biol. Chem. 2006; 281: 7809-7815.

24. Koch A., Hofbeck M., Feistel H. Circumscribed intestinal protein loss with deficiency in CD4+ lymphocytes after the Fontan procedure. Eur. J. Pediatrics 1999; 158: 847-850.

25. Lenz D., Hambsch J., Sauer U. i wsp. Detection of allo- and autoreactive antibodies in patients with protein-losing enteropathy (PLE) in Fontan patients by flow and laser scanning cytometry. J. Biol. Regul. Homeost. Agents 2001; 15: 474.

26. Ohhashi T., Watanabe N., Kawai Y. Effects of atrial natriuretic peptide on isolated bovine mesenteric lymph vessels. Am. J. Physiol. 1990; 259: $\mathrm{H} 42-\mathrm{H} 27$.

27. Cohen M.I., Bush D.M., Ferry R.J. Jr. i wsp. Somatic growth failure after the Fontan operation. Cardiol. Young. 2000; 10: 447-457.

28. Fujii T., Shimizu T., Takahashi K. i wsp. Fecal alpha1-antitrypsin concentrations as a measure of enteric protein loss after modified fontan operations. J. Pediatr. Gastroenterol. Nutr. 2003; 37: 577-580.

29. Thorne S.A., Hooper J., Kemp M., Somerville J. Gastro-intestinal protein loss in late survivors of Fontan surgery and other congenital heart desease. Eur. Heart J. 1998; 19: 514-520.

30. Hill G.E. Cardiopulmonary bypass-induced inflammation: is it important? J. Cardiothorac. Vasc. Anesth. 1998; 12: 21-25.

31. Mavroudis C., Deal B.J., Backer C.L. i wsp. 111 Fontan conversions with arrhythmia surgery: surgical lessons and outcomes. Ann. Thorac. Surg. 2007; 84: 1457-1466.

32. Weinstein S., Chan D. Extracardiac Fontan conversion, cryoablation, and pacemaker placement for patients with a failed Fontan. Semin. Thorac. Cardiovasc. Surg. 2005; 17: 170-178.

33. Marcelletti C.F., Hanley F.L., Mavroudis C. i wsp. Revision of previous Fontan connections to total extracardiac cavopulmonary anastomosis a multicenter experience J. Thorac. Cardiovasc. Surg. 2000; 119: 340-346.

34. Cohen M.I., Rhodes L.A., Wernovsky G., Gaynor J.W., Spray T.L., Rychik J. Atrial pacing: an alternative treatment for protein-losing enteropathy after the Fontan operation. J. Thorac. Cardiovasc. Surg. 2001; 121: 582-583.

35. Vyas H., Driscoll D.J., Cabalka A.K., Cetta F., Hager D.J. Results of transcatheter Fontan fenestration to treat protein-losing enteropathy. Catheter. Cardiovasc. Interv. 2007; 69: 584-589.

36. Mertens L., Dumoulin M., Gewillig M. Effect of percutaneous fenestration of the atrial septum on protein-losing enteropathy after the Fontan operation. Br. Heart J. 1994; 72: 591-592.

37. Bridges N.D., Lock J.E., Mayer J.E. Jr, Burnett J., Castaneda A.R. Cardiac catheterization and the test occlusion $f$ the interatrial communication after the fenestrated Fontan operation. J. Am. Coll. Cardiol. 1995; 25: 1712-1717.

38. Ringel R.E., Peddy S.B. Effect of high-dose spironolactone on protein-losing enteropathy in patients with Fontan palliation of complex congenital heart disease. Am. J. Cardiol. 2003; 91: 1031-1032, A9.

39. Uzun O., Wong J.K., Bhole V., Stumper O. Resolution of protein-losing enteropathy and normalization of mesenteric Doppler flow with sildenafil after Fontan. Ann. Thorac. Surg. 2006; 82: e39-e40. 
40. Haseyama K., Satomi G., Yasukochi S. i wsp. Pulmonary vasodilation therapy with sildenafil citrate in a patient with plastic bronchitis after the Fontan procedure for hypoplastic left heart syndrome. J. Thorac. Cardiovasc. Surg. 2006; 132: 1232-1233.

41. Rothman A., Snyder J. Protein-losing enteropathy following the Fontan operation: resolution with prednisone therapy. Am. Heart J. 1991; 121: 618-619.

42. Rychik J., Piccoli D.A., Barber G. Usefulness of corticosteroid therapy for protein-losing enteropathy after the Fontan procedure. Am. J. Cardiol. 1991; 68: 819-821.

43. John A.S., Driscoll D.J., Warnes C.A., Phillips S.D., Cetta F. The use of oral budesonide in adolescents and adults with protein-losing enteropathy after the Fontan operation. Ann. Thorac. Surg. 2011; 92: 1451-1456.

44. Schumacher K.R., Cools M., Goldstein B.H. i wsp. Oral Budesonide Treatment for Protein-Losing Enteropathy in Fontan-Palliated Patients. Pediatr. Cardiol. 2011; 32: 966-971.
45. Donnelly J.P., Rosenthal A., Castle V.P., Holmes R.D. Reversal of protein-losing enteropathy with heparin therapy in three patients with univentricular hearts and Fontan palliation. J. Pediatr. 1997; 130: 474-478.

46. Jahangiri M., Ross D.B., Redington A.N., Lincoln C., Shinebourne E.A. Thromboembolism after the Fontan procedure and its modifications. Ann. Thorac. Surg. 1994; 58: 1409-1414.

47. Jayakumar K.A., Addonizio L.J., Kichuk-Chrisant M.R. i wsp. Cardiac transplantation after the Fontan or Glenn procedure. J. Am. Coll. Cardiol. 2004; 44: 2065-2072.

48. Kanter K.R., Mahle W.T., Vincent R.N., Berg A.M., Kogon B.E., Kirshbom P.M. Heart transplantation in children with a Fontan procedure. Ann. Thorac. Surg. 2011; 91: 823-830.

49. Bernstein D., Naftel D., Chin C. i wsp. Outcome of listing for cardiac transplantation for failed Fontan: a multi-institutional study. Circulation 2006; 114: 273-280. 